\title{
Alterations of blood indices associated with low-dose administration of methomyl insecticide for short times to albino rats
}

\author{
Ismael IS Abdel Aziz, ${ }^{\text {* }}$ \&Baker MH Zabut ${ }^{2}$ \\ ${ }^{1}$ Biology Department, Faculty of Science, Islamic University of Gaza, Gaza, Palestine \\ ${ }^{2}$ Biochemistry Dept., Faculty of science, Islamic University of Gaza, Gaza, Palestine
}

\begin{abstract}
The study aimed to investigate haematological and biochemical alterations associated with shortterm intraperitoneal sublethal (1/10 $\mathrm{LD}_{50}, 2 \mathrm{mg} / \mathrm{kg}$ body weight) methomyl administration to male albino rats over two and five days, and also the effects of a two-week recovery period. Methomyl administration over five but not two days decreased mean corpuscular hemoglobin and mean corpuscular hemoglobin concentration. A number of blood biochemical parameters increased (serum glucose, cholesterol, triglycerides, urea, uric acid, creatinine) or decreased (globulin); a recovery period returned many entirely or nearly to control levels. Enzyme activities (ALP, ALT, AST) and bilirubin levels increased following methomyl treatment, but again returned to control levels following a recovery period. We conclude that short low doses of methomyl can harm the blood, kidney and liver of rats.
\end{abstract}

Keywords: methomyl insecticide, hematology and biochemical alternations, male rats.

\section{Introduction}

The environmental contamination by insecticides used extensivelyin agriculture has become a serious health problem, and their harmful effects on the body when ingested by humans and farm animals have generated considerable interest. Carbamate insecticides are toxic to humansin that they can interfere with various vital mechanisms (Haddad \& Winchester, 1983). They are synthetic derivatives of carbomic acid and constitute the most widely used chemical type of pesticides for insect control. Several deaths among farmers in the Gaza Strip have been proved to be the result of use and misuse of pesticides, where precautions regarding the wearing of protective clothes during application and handling, and the timing, frequency and preharvesting interval, are all poorly followed (Abd-Rabou \& Al-Agha, 1998). Unfortunately the use of insecticides is unavoidable to protect crops from insects and to increase farm incomes, especially in apoor area such as the Gaza Strip.

More than 450 metric tonnes of formulated pesticides are used annually in the very densely populated area in the Gaza strip; many of them are banned internationally (Safi et al., 1993; Safi, 1995). The excessive and irresponsible use of pesticides could result in an apparent leakage of these insecticides into ground water (US EPA, 1990), the main source of drinking water in the Gaza Strip. 70-100 tonnes of insecticides are used every year in the Gaza strip (Ministry of Agriculture, 2009).

Shakoori et al. (1992) reported that oral administration of the insecticide Danitol to rabbits at a dose of $10 \mathrm{mg} / \mathrm{kg}$ body wt for seven days produced significant decrease in red blood cell counts andhaemoglobin content, and increasedwhite blood cell counts.Zaahkook et al., (2009) evaluated the toxic effects of imidacloprid insecticide and the possible ameliorating role of vitamins on Japanese quails. They observed significant increases and decreases in various biochemical and blood parameters.

Although many studies have been carried out to study the toxic effect of methomyl insecticideon laboratory animals, and even though considerable progress regarding its effects in vivo has been made, information about the effects of low doses of methomyl andthe

\footnotetext{
* Author for correspondence: tel 0598884729email : iaziz@iugaza.edu.ps
} 
recovery time oftreated animals is still controversial and unclear. The objective of the present study is, therefore, to assess haematological and biochemical changes in rats administrated low dose $\left(1 / 10 \mathrm{LD}_{50}\right)$ of methomyl.

\section{Materials \& Methods}

The study used adult male Rattus norvegicus albino rats weighing 150-200 g,purchased from the breeding unit of the Biology Department, Faculty of Science, Islamic University of Gaza. Rats were left in the animal house for one week before experimentation to adapt to laboratory conditions. Animals were housed in plastic cages with wire mesh covers under the following conditions: temperature $20-21^{\circ} \mathrm{C}$, relative humidity $40-60 \%$ and a photoperiod regime of 14L:10D. Cage bottoms were lined with freshly spread wood dust to absorb the urine. Rats were given free access to commercial balanced diet and water throughout the experimental period. They were divided into four groups, six per cage, as follows:Group I (control) injected intraperitoneally with distilled water; II - injected daily with methomyl $(2 \mathrm{mg} / \mathrm{kg}$ bwt $)$ for two days; III - injected daily with methomyl ( $2 \mathrm{mg} / \mathrm{kg}$ bwt) for five days; IV- injected daily with methomyl ( $2 \mathrm{mg} / \mathrm{kg}$ bwt) for five days and then left untreated for two weeks (to study the effects of recovery).

All chemicals used were of analytical grade, purchased from Sigma Chemical Company, Germany. The methomyl insecticide was obtained as a commercial product from local markets from Gaza city in sealed bottles.

At the end of the experiment, animals were decapitated and approximately $5 \mathrm{~mL}$ of blood collected into centrifuge tubes without any anticoagulant. The centrifuge tubes were left for about $15 \mathrm{~min}$ to allow blood coagulation. Clear serum samples were separated by centrifugation at $3000 \mathrm{rpm}$ for $20 \mathrm{~min}$ and kept in the refrigerator for biochemical assays. Determinations of enzyme activities were carried out on fresh serum samples.For haematological tests, about $2 \mathrm{~mL}$ of blood samples were transferred into a tube containing dipotasium ethylene diamine tetra acetate (EDTA).Determination of haematological parameters was carried out using an automated 18-parameter hematology analyzer (ABX Micros 60 from Horiba ABX, France).

The blood indicesserum glucose, triglycerides and total cholesterol were determined using the methods described by Trinder(1969), Fossati \& Prencipe (1982) and Allain et al. (1974), respectively. Serum urea measurement was based on the cleavage of urea with urease (Berthelot's reaction),following Faweett\&Scott (1960).Serum uric acid was determined following the method described by Fossati et al (1980).Serum creatinine was measured without protein precipitation according to Bartels et al (1972).Serum total protein was determined according to the Biuret reaction as designed by Armstrong \&Carr (1963).Kits were purchased from Biotech laboratories, UK.

Serum albumin was determined using RANDOX reagent kits, following the instruction manual and according to the method of Doumas et al. (1971). The concentrations of globulins $(\mathrm{g} / \mathrm{dL})$ were equal to total protein - albumin. The activities of serum aspartate transaminase (AST) and alanine transaminase (ALT) were determined according to the method of Reitman $\&$ Frankel (1957). The measurement of serum alkaline phosphatase (ALP)activity and bilirubin were based on the method of Bessey et al (1946).

Data were analyzed using SPSS version 13 for windows. One way ANOVA testedfor differencesamong the groups, particularly against the control.Differences were considered significant if $\mathrm{p}<0.05$. 


\section{Results}

The red blood cell count generally decreased in response to administration with methomyl insecticide, but changes were not significantly different from the control (Table 1). The decrease in red blood cell countwas slightly more pronounced after five days of methomyl administration. Many other indices also tended to decrease but only in the cases of the mean cell haemoglobin and mean cell haemoglobin concentration were these decreases significant, and only for the treatment of daily administration for five days (Table 1). There was a general increase in mean cell volume and white cell counts, but these were also not significant.

\begin{tabular}{|c|c|c|c|c|}
\hline \multirow{2}{*}{ Hematological indices } & \multirow[b]{2}{*}{$\begin{array}{l}\text { Group I } \\
\text { (control) }\end{array}$} & \multicolumn{3}{|c|}{ Experimental groups } \\
\hline & & $\begin{array}{l}\text { Group II } \\
(2 \text { doses })\end{array}$ & $\begin{array}{l}\text { Group III } \\
\text { (5 doses) }\end{array}$ & $\begin{array}{c}\text { Group IV } \\
\text { (Recovery) }\end{array}$ \\
\hline WBC count $\left(\times 10^{3}\right.$ cell $\left./ \mu \mathrm{l}\right)$ & $6.77 \pm 0.24$ & $6.83 \pm 0.60$ & $6.90 \pm 0.33$ & $6.71 \pm 0.45$ \\
\hline $\mathrm{RBC}$ count $\left(\times 10^{6}\right.$ cell $\left./ \mu \mathrm{l}\right)$ & $6.66 \pm 0.42$ & $6.38 \pm 0.29$ & $6.27 \pm 0.40$ & $6.55 \pm 0.35$ \\
\hline $\mathrm{Hb}(\mathrm{g} / \mathrm{dl})$ & $13.98 \pm 0.70$ & $12.65 \pm 0.51$ & $11.40 \pm 0.31$ & $12.82 \pm 0.26$ \\
\hline Hematocrit (PCV) (\%) & $38.77 \pm 1.02$ & $38.22 \pm 3.19$ & $36.95 \pm 2.93$ & $37.86 \pm 3.30$ \\
\hline $\operatorname{MCV}(\mathrm{fi})$ & $58.21 \pm 0.37$ & $59.91 \pm 0.36$ & $58.93 \pm 0.45$ & $57.80 \pm 0.41$ \\
\hline $\mathrm{MCH}(\mathrm{pg})$ & $20.99 \pm 0.39$ & $19.83 \pm 0.52$ & $18.18 \pm 0.58 *$ & $19.57 \pm 0.46$ \\
\hline $\mathrm{MCHC}(\mathrm{g} / \mathrm{dl})$ & $36.06 \pm 0.40$ & $33.1 \pm 0.47$ & $30.85 \pm 0.65 *$ & $33.86 \pm 0.50$ \\
\hline Platelets $\left(\times 10^{3}\right.$ cell $\left./ \mu \mathrm{l}\right)$ & $676.5 \pm 66.4$ & $665.8 \pm 25.9$ & $652.0 \pm 49.7$ & $670.5 \pm 30.6$ \\
\hline
\end{tabular}

Table 1: Haematological indices of adult male albino rats administered methomyl insecticide. All values were expressed as mean \pm s.e. ( $\mathrm{n}=6$ rats in all groups). Stars $(*)$ indicate values significantly different from the control $(\mathrm{p}<0.05)$. WBC - white blood count; RBC -red blood cell count; $\mathrm{Hb}$ - haemoglobin; MCV - mean cell volume; $\mathrm{MCH}$ - mean cell haemoglobin; MCHC - mean cell haemoglobin concentration.

\begin{tabular}{|c|c|c|c|c|c|c|c|}
\hline \multirow[b]{2}{*}{ Blood chemical indices } & \multicolumn{7}{|c|}{ Experimental groups } \\
\hline & $\begin{array}{r}\text { Group I } \\
\text { (control) }\end{array}$ & $\begin{array}{c}\text { Group II } \\
\text { (2 doses) } \\
\end{array}$ & & $\begin{array}{c}\text { Group III } \\
\text { (5 doses) } \\
\end{array}$ & & $\begin{array}{l}\text { Group IV } \\
\text { (recovery) }\end{array}$ & \\
\hline Glucose (mg/dl) & $128.51 \pm 4.38$ & $183.97 \pm 6.17$ & $* *$ & $192.0 \pm 5.18$ & $* *$ & $166.0 \pm 7.17$ & $* *$ \\
\hline Cholesterol (mg/dl) & $74.83 \pm 2.24$ & $76.44 \pm 4.13$ & & $96.5 \pm 2.61$ & $* *$ & $90.5 \pm 3.35$ & $* *$ \\
\hline Triglycerides (mg/dl) & $61.50 \pm 3.60$ & $63.46 \pm 3.11$ & & $68.70 \pm 2.13$ & $*$ & $66.0 \pm 3.19$ & \\
\hline Urea $(\mathrm{mg} / \mathrm{dl})$ & $26.83 \pm 0.79$ & $29.18 \pm 0.66$ & & $31.0 \pm 0.75$ & $*$ & $27.25 \pm 0.90$ & \\
\hline Uric acid (mg/dl) & $1.30 \pm 0.07$ & $1.91 \pm 0.66$ & $* *$ & $2.55 \pm 0.04$ & $* *$ & $1.65 \pm 0.08$ & $* *$ \\
\hline Creatinine (mg/dl) & $0.43 \pm 0.06$ & $0.81 \pm 0.04$ & $* *$ & $0.95 \pm 0.07$ & $* *$ & $0.72 \pm 0.05$ & $* *$ \\
\hline Total protein (mg/dl) & $5.76 \pm 0.16$ & $5.41 \pm 0.13$ & & $5.39 \pm 0.15$ & & $5.73 \pm 1.14$ & \\
\hline Total albumin (mg/dl) & $3.50 \pm 0.12$ & $3.45 \pm 0.11$ & & $3.46 \pm 0.12$ & & $3.49 \pm 0.15$ & \\
\hline Total globulin (mg/dl) & $2.26 \pm 0.11$ & $1.95 \pm 0.12$ & $*$ & $1.93 \pm 0.13$ & $*$ & $2.24 \pm 0.12$ & \\
\hline $\operatorname{ALP}(\mathrm{U} / \mathrm{L})$ & $386.7 \pm 14.3$ & $510.2 \pm 16.6$ & $* *$ & $659.5 \pm 17.7$ & $* *$ & $411.5 \pm 15.6$ & \\
\hline ALT (U/L) & $136.33 \pm 5.83$ & $142.92 \pm 6.5$ & & $156.11 \pm 7.2$ & $*$ & $139.5 \pm 5.72$ & \\
\hline AST (U/L) & $32.50 \pm 1.52$ & $68.81 \pm 1.71$ & $* *$ & $43.14 \pm 2.19$ & $* *$ & $33.05 \pm 1.88$ & \\
\hline Bilirubin $(\mathrm{mg} / 100 \mathrm{ml})$ & $0.48 \pm 0.05$ & $0.51 \pm 0.06$ & & $0.56 \pm 0.04$ & $*$ & $0.50 \pm 0.03$ & \\
\hline
\end{tabular}

Table 2: Chemical blood indices of adult male albino rats administered methomyl insecticide. All values represented as mean \pm S.E and $\%$ of change from the control

Methomyl caused a number of changes in blood chemical parameters (Table 2). There were significant increases in urea concentration, uric acid and creatinine, with changes in uric 
acid being especially large. Methomyl also caused significant increases in glucose and cholesterol; the triglyceride content increased only after five days of treatment. There were also decreases in the levels of total protein, albumin and globulin concentrations compared to the control, but the changes were only significant globulin.

In general, the activity of ALT, AST and especially ALP increased in response to administration of methomyl insecticide (Table 2), but after a recovery period these indices were reduced and no longer significantly different from the control.

\section{Discussion}

The red blood cell count showed a general but non-significant decrease in response to methomyl administration, unlike for other insecticides (Shakoori et al., 1992; Abdel Aziz, 2000). Thus we failed to confirm any inhibitory effect of methomyl on histogenesis. There was a decrease in haemoglobin, which should have lowered the oxygen supply to different tissues and resulted in low energy production. The decrease in haemoglobin in the corpuscles is perhaps due to impaired biosynthesis of haeme in the bone marrow. Significant decreases in red blood cell counts and haemoblobin content were shown in response to administration of similar levels of tamaron, parathion and confidor (Kerrit et al., 1999) and some other pesticides (Abdel Aziz, 2000; Yassin et al., 2002).

Several authors reported that a plastic anaemia and bone-marrow failure could occur following exposure to insecticides (Fishein, 1976; Jenkyn et al., 1979). Reevese et al. (1981) described cases of plastic anaemia and acute leukaemia in children associated with household insecticides. Similarly, Fisbein (1976) reported leucopenia in rabbits exposed to dithiocarbamate derivatives; Singh et al. (1992) reported significant decreases in several blood parameters after exposure of Indian catfish to low concentrations of propoxur; and Abul-Naser \& Bassiouni (1994) reported similar decrease in response to Baygon spray. Insecticides may also inhibit delta-aminolevulinic acid dehydrates, which play a major role in haemosynthetic pathways (Chiba \& Kikuchi, 1983).

Urea is the principal end product of protein catabolism. Enhanced protein catabolism and accelerated amino acid deamination for gluconeogenesis is probably an acceptable postulate to interpret the elevated level of urea. This elevation in urea might be also due to the destruction of red blood cells during the treatment. The presence of some toxic compounds may increase blood urea and decrease plasma protein (Varely, 1976; Ashour, 1999; Zaahkook et al., 2009). Elevation of blood urea is a good indicator for kidney diseases, but an increase in urea might also suggest that animals experienced hemoconcentration due to mild dehydration (Guilhermino et al., 1998). Serum uric acid levels exhibited significant increases in treated rats. This may be due to high degradation of purines, or an increase of uric acid levelscaused by an inability to excrete by the urinary system (Wolf et al., 1972). A rise in blood creatinine levels is observed with damage to functioning nephrons and impaired renal function (Ledwith et al., 1997).

Methomyl caused a significant increase in glucose content of rat blood serum. Insecticides may directly or indirectly play a specific role in pancreatic secretion (Abdel Aziz, 2000). Gluconeogenesis produces glucose from the carbon skelton of glucogenic amino acids and glycolytic intermediates. The finding of high glucose levels means that there was a disturbance in carbohydrate metabolism.

The changes observed in serum triglycerides and cholesterol content in response to methomyl take place in the liver due to an imbalance between the normal rates of lipid synthesis, utilization and secretion (Glasser \& Mager, 1972). The increment in cholesterol and triglyceride content agrees with those reported by Parker et al. (1984), Yassin et al. (2002) and Zaahkook et al. (2009). 
Similar findingsof decreases in the levels of total protein, albumin and globulin concentrations were reported in other studies as a result of oral administration of various pesticide doses (Zaahkook et al., 2009; Esleem 2010). This decrease in serum total protein may be due to lowered synthesis of albumin and globulin in the liver in response to methomyl intake. It was reported that albumin levels are decreased in liver disease (Nyblom et al., 2004). The decrease in the rat blood proteins may be due to usage of different amino acids in production of antibodies in the liver in response to methomyl administration.

Serum ALT and AST are typically considered to be sensitive markers employed in the diagnosis of hepatotoxicity. The increases in ALT and AST activity in response to the administration of methomyl agree with those observed by Guilhermino et al. (1998) and Ashour (1999) for parathion administration. The elevation in serum transaminase activitywas also noticed by Regon et al. (1994) for carbaryl, which suggests liver injury (Guilhermino et al., 1998; Kutlu et al., 2005), and may be attributable to some cell damage leading to leakage of enzymes into the blood (Dewan et al., 2004).

Funakoshi et al. (1995) reported that parathion and cadmium increased serum enzymes (ALT, AST and ALP). Pesticide exposure causes liver damage and leakage of cytosolic enzymes from haepatocytes and other body organs into the blood (Dewan et al., 2004). Elevation of liver enzymes may also be due to increased gene expression due to the long-term requirements of detoxification of pesticides (Friedman et al., 2003). Bell \& Freeman (1971) reported that a high ALP activity is known to occur in cells or tissues exhibiting either a high turnover or high anabolic rate. Kaur et al. (2006), Zaahkook et al. (2009) and Esleem (2010) reported that ALP increased during the first three weeks in animals treated with different doses of imidacloprid.

After a period of recovery after methomyl admiminstration, the previous changes in blood indices showed signs of reversal. Thus, fortunately, the various effects of short periods of exposure to methomyl in rats were relieved with time.

\section{Acknowledgements}

The author would like to thank Mr Al-Monther I. El-Hamedi for printing this manuscript.

\section{References}

Abd El-Aziz I (2000) Hematological and biochemical study on rabbit post whole-body X-irradiation and treatment by Nigella sativa oil or olive oil. Journal of PestControl \& Environmental Sciences 8(1): 56-84

Abd Rabou A \& Al-Agha M (1998) Environmental awareness in handling and application of pesticides among farmers in Rafah governorate-Gaza Strip. The Vth International HCH and Pesticide Forum, Bilbao, Spain. June, 25-27, 1998.

Abul-Naser MS \& Bassiouni SH (1994) Haematological and ultra-structural study on the effect of Propoxur (Baygon) on the bone marrow of male albino rats. Egyptian Journal of Histology 17(2): 389-402

Allain CC, Poon LS, Chan CSG, Richmond W \& Fu PC (1974) Enzymatic determination of total serum cholesterol. Clinical Chemistry 20(4): 470-72

Armstrong WD \& Carr CW (1963)Physiological chemistry: laboratory directions. $3^{\text {rd }}$ ed. Minneapolis, Minnesota, USA: Burges Publishing Co.

Ashour A (1999) Comparative study on the effect of some insecticides administration on protein content and some enzymes of rabbit's serum. Annual Review for Arts, Science \& Education, Faculty of Women, Ain Shams University: Science section 20: $72-87$

Bartles H, Bohmer M \& Heierli C (1972) Serum creatinine determination without protein precipitation. Clinica Chimica Acta 37: 193-197

Bell DJ \& Freeman BM (1971)Physiology and biochemistry of the domestic fowl. Vol. 2, Academic Press, London.

Bessey OA, Lowry DH \& Brock JM (1946) Method for the determination of alkaline phosphatase with five cubic milliliters of serum. Journal of Biological Chemistry 146:321

Chiba K \& Kikuchi M (1983) The in vivo effect of manganese and zinc-aminolevulinic acid dehydrate activity inhabited by lead. Toxicology Letters 20: 143-147

Dewan A, Bhatnager VK, Mathur M, Chakama T, Kashyap R, Sadhu HG, Sinha SK\& Saiyed HN (2004) Repeated episodes of endosulphan poisoning. ClinicalToxicology 42(4): 363-369 
Dumas BT, Watson WA \& Bis HG (1971) Albumin standards and the measurement of serum albumin with bromocresol green. Clinica Chemica Acta 31: 87-96.

Esleem NE (2010) Physiological and histological studies on inidacloprid toxicity in male rabbits. MSc Thesis, Faculty of Science, Islamic University of Gaza, Gaza.

Fawcett JK \&Scott JE (1960) A rapid and precise method for the determination of urea. Journal of Clinical Pathology 13: 156-159

Friedman LS, Brautbar N, Barach P, Wolfe A\& Richter ED (2003)Creatine phosphate kinase elevations signaling muscle damage following exposures to anticholinesterases: 2 sentinel patients. Archives of Environmental Health 58(3): 167-71

Fisbein L (1976) Environmental health aspects of fungicides I - dithiocarbamates. Journal of Toxicology \& Environmental Health 1: 713-735

Fossati P, Prencipe L \& Berti G (1980) Use of dichloro-2-hydroxy-benzenesulfonic acid/ 4-aminophenazone chromogenic system indirect enzyme assay of uric acid in serum and urine. Clinical Chemistry 26: 227231

Fossati P\& Prencipe L (1982) Serum trilycerides determined colorimetrically with an enzyme that produces hydrogen peroxide, Clinical Chemistry 28(10): 2077-8

Funakoshi T, Ohta O, Shimada H\& Kojima S (1995) Effects of dithiocarbamates and cadmium on enzymatic activities in liver, kidney and blood of mice. Toxicology Letters 78: 183-188

Glaser G \& Mager J (1972) Biochemical studies on the mechanism of liver poisons. II. Induction of fatty liver. Biochemica \& Biophysica Acta 261: 500

Guilhermino L, Soares AMVM, Caenalho AP\& Lopes MC (1998) Effects of cadmium and parathion exposure on hematology and blood biochemistry of adult male rats. Bulletin of Environmental Contamination \&Toxicology 60: 52-59

Haddad LM\& Winchester JF (1983) Clinical management of poisoning and drug overdose. WB Saunders \&Co., Philadelphia, London, Toronto: 364-373.

Jenkyn LR, Budd RC \& Fein SH (1979) Insecticide/herbicide exposure, aplastic anemia and pseudotuour cerebri. Lancet, 18:368.

Kaur B, Sandhu HS\& Kaur R (2006) Toxic effects of subacute oral exposure of imidaclopid on biochemical parameters in crossbred cow calves. Toxicology International 13(1): 49-52

Kerrit A, Yassin M, Abd El-Aziz I \& Ashour A (1999) Hematological study on the effect of oral administration of some insecticides on rabbit's blood. Annual Review for Arts, Science \& Education, Faculty of Women, Ain Shams University: Science section 20

Kutlu S, Colakoglu N, Halifeoglu I, Sanadal S, Seyran AD, Aydin M \& Yilmaz B (2005) Comparative evaluation of hepatotoxic and nephrotoxic effect of aroclors 1221 and 1254 in female rats. Cell Biochemistry \& Function 25(2): 167-172

Ledwith BJ, Pauley CJ, Wanger LK et al. (1997)Induction of cyclooxygenase-2 expression by peroxisome proliferators and non-tetradecanoylphorbol 12,13-myristate-type tumor promoters in immortalized mouse liver cells. Journal of Biological Chemistry 272: 3707-3714

Ministry of Agriculture (2009) Palestinian National Authority, personal communication.

Nyblom H, Berggren U, Balldin J et al. (2004) High Astialt ratio may indicate advanced alcoholic liver disease rather than heavy drinking alcohol. Alcohol 39: 336-339

Parker CM, Piccirillo VJ, Kuriz SL, Graner FM, Gradiner T \&Vangelde GA (1984) Six-month synthetic feeding study of fenvalerate in dogs. Fundamentals of Applied Toxicology 4: 577-58

Reeves JD, Driggers AD \& Kiley VA (1981) Household insecticides associated aplastic anaemia and acute leukemia in children (Letter). Lancet 8; 2(8241): 300-301

Reitman S \& FrankelS (1957) A colorimetric methid for the determination of serum glutamic oxaloacetic and glutamic pyruvic transaminases activity. American Journal of Clinical Pathology 28: 56-63

Rigon AR, Reis M \&Takahashi RN (1994) Effects of carbaryl on some dopaminergic behaviours in rats.General Pharmacology 25(6): 1263-1267

Safi JM, El-Nahhal YZ, Soliman SA \& El-Sebae AH (1993) Mutagenic and carcinogenic pesticides used in the agricultural environment of Gaza Strip. Science of the Total Environment 132: 371-380

Safi JM (1995) Special problems associated with pesticide use and its management in Gaza Strip. Journal of Occupational Medicine 19: 267-276

Shakoori AR, Butt U, Riffat R \& Aziz F (1992) Toxic effects of short- term oral administration of Danitol on the blood and liver of rabbits. Punjab University Journal of Zoology 7: 13-26

Singh NN,Srivastava AK \&Srivastava AK (1992) Blood dyscrasia in fresh water Indian catfish Heteropneustes fossilis after acute exposure to a sublethal concentration of propoxur. Acta Hydrobiologica 34(1-2): 189-95

Trinder P (1969) Determination of glucose in blood glucose oxidase with an alternative oxygen acceptor. Annals of Clinical Biochemistry 6: 24-27

US Environmental Protection Agency (1990) National pesticide survey: summary results of EPA's national survey of pesticides in drinking water wells. Office of Water/Office of Pesticides and Toxic Substances. 
Varely H (1976) Practical clinical biochemistry. 4th edition.

Wolf PL, Williams D, Tsudaka T \& Acosta L (1972)Methods and techniques in clinical chemistry. Wiley-Inter science,New York, London, Sydney, Toronto.

Yassin MM, Abu Mourad TA \& Safi JM (2002) Knowledge, attitude, practice and toxicity symptoms associated with pesticide use among farm workers in the Gaza Strio. Occupational \& Environmental Medicine 59: 387-393

Zaahkook SA, Helal EG, Fahmy N, Al-Shinnawy MS\& El-Ghany AB (2009) Physiological study about imidacloprid toxicity and the role of vitamin"C" as a protective agent on Japanese Quails. Egyptian Journal of Hospital Medicine 34:183-197

\section{الملخص العربيى}

تأثير حقن فئران التجارب بجرعة قليلة من مبيد الميثومايل لفترات قصيرة على قياساتها الدموية

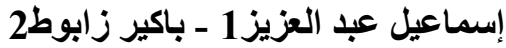

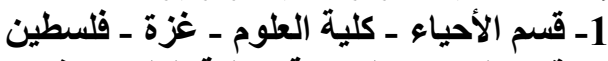

2- قسم الكيمياء الحيوية ـ كلية العلوم ـ غزة ـ فلطين ـ فلسطين

تهدف هذه الاراسة إلى تقدير التأثير السام الناتج عن حقن ذكور الفئران البيضاء البالغة في تجويف البطن بمبيا

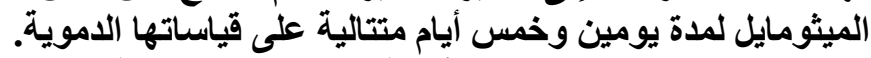

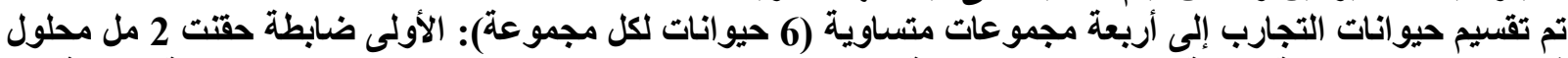

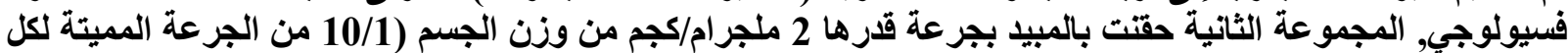

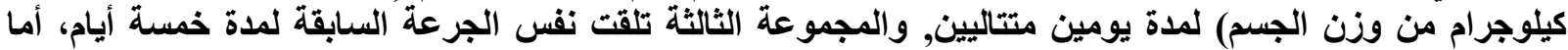

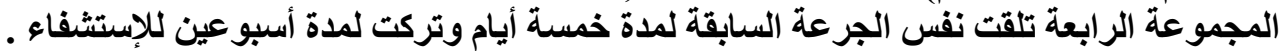

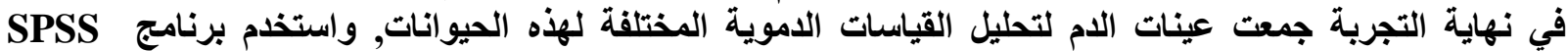
version 13

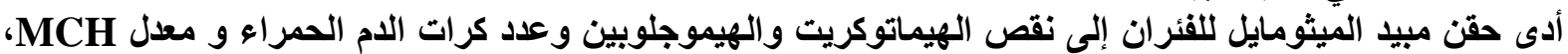
MCHC

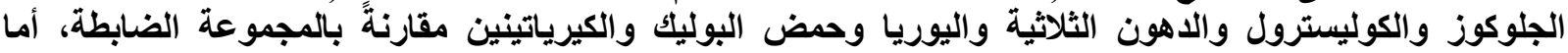

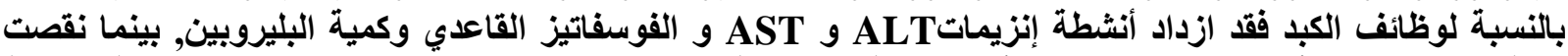

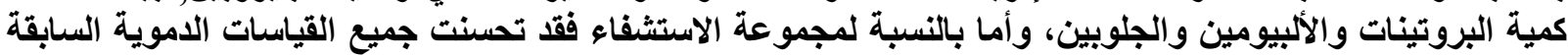

مما سبق يمكن أن نستنتج أن إعطاء فئران التجارب الذكور مبيد الميثومايل مدد زمنية قصيرة وبجرعات قليلة يحدث تأثيرات ضارة على قياسات الام ووظائف الكلى والكباء. 